DOI https://doi.org/10.36059/978-966-397-109-4/93-113

\title{
GENDER DISCRIMINATION: VIEW OF STUDENT YOUTH
}

\section{Kostina T. O.}

\section{INTRODUCTION}

Today, the issue of discrimination in general and its varieties is acute in Ukraine, which manifests itself in the form of gender-based discrimination. Despite the fact that attention to this issue is already at the state level, which is manifested in the adoption of relevant laws that should reduce the level of discrimination in Ukrainian society.

Adoption of the relevant legislative acts requires from Ukraine representatives of the European Union and other countries of a democratic society. It is clear that any actions, deeds or inactions of a person in a society should be regulated by the relevant legislation. The existence of such laws can appeal to the establishment and observance of certain rules of conduct that are not harmful to people and are consistent with the basic principles of democracy.

It should be noted that apart from a purely legal plane, any phenomenon also has a psychological component. The psychological plane contains certain "unwritten" rules, norms of behavior, which usually contain the context of ethics and morality. However, everyday life often encounters "rules" that in their essence contradict generally accepted human values and thus provide the basis for the deployment of various negative phenomena. One of these negative manifestations is discrimination, in particular, gender-based discrimination.

We emphasize that no norm that functions in one or another society can not go against the democratic values of freedom and equality. Is that really true? And can socio-psychological stereotypes really be overcome through legal action? In our opinion, only the legal plane is not enough. Particularly in the subject of discrimination, which "cling" to the deep levels of the human psyche. 
That is why it is important for us to investigate the psychological aspect of this phenomenon and, based on the findings, to create optimal conditions for the formation of gender equality in the territory of Ukrainian society.

The main purpose of this article is to determine the specificity of the attitude and level of awareness about gender inequality among the student youth. Our scientific research focused on the study of the views of young people (students) on this issue, because it is the young people who can become the driving force that will help to overcome inequalities in Ukraine. After all, they are the future of our country, and first and foremost depends on them, which way the Ukrainian state and society will go.

\section{Approaches to the definition of discrimination. Gender discrimination}

To understand the concept of gender discrimination, it is necessary to clarify the original components: the concept of "discrimination" and "gender".

The term "discrimination" comes from the Latin "discriminatio" and literally translates as "distinguish". According to S. Ozhegov's explanatory dictionary, discrimination is denoted as: "to restrict rights, to deprive equal rights" . Discrimination in the Ukrainian language dictionary is defined as: "restriction or deprivation of the rights of certain categories of citizens by race or nationality, political or religious beliefs" 2 .

The Cambridge Dictionary denotes discrimination as a practice of dealing with a person or group of people less equally than other people. Typically, the factors that lead to manifestations of discriminatory behavior are the color of the skin, gender, age, race $^{3}$.

The word "gender" was originally used in linguistics to refer to the notion of gender as a grammatical category. Later, the term was fixed in the socio-psychological plane.

The term delineates the concept of biological sex and social. Biological gender refers to the biological, anatomical and physiological differences between the organisms of women and men. It is these differences that ensure the reproduction of the body. For a deeper understanding of the concept of sex, we will analyze the concept proposed

\footnotetext{
${ }^{1}$ Ожегов С.И., Шведова Н.Ю. Толковый словарь русского языка (А-Д) Издательство “Азъ”,

2 Словник української мови : [в 11-ти т.] / [ред. кол.: І.К. Білодід (гол.) та ін.]. Київ: Наукова думка, 1970-1980. Т. 2: Г-Ж / ред. тому:П.П. Доценко, Л.А. Юрчук. 1971.550 с.

${ }^{3}$ Кембриджський словник. URL: https://dictionary.cambridge.org/
} 
by the American psychologist John Mani who identified eight stages of sexual differentiation:

1) chromosomal or genetic sex (genotype: $\mathrm{XX}$ or $\mathrm{XY}$ );

2) gonadal sex (ovaries / testicles);

3) gametta sex (sperm / egg);

4) hormonal sex (androgen and testosterone / estrogen and progesterone);

5) morphological (somatic) sex (penis / clitoris and vagina);

6) civic sex (phenotype: male / female);

7) sex, which arose as a result of education;

8) sexual identity ${ }^{4}$.

The first six stages of J. Mani are called biological, the last two psychological. The formation of a "psychological" gender is due to social roles that pass into the gender of the biological. Clarify the notion of a sexual role.

Sexual role is a system of norms and regulations concerning the behavior of men and women taken in a particular social environment. Behavior, which is consistent with the accepted distribution of sexual roles in a given society, is called sexually typed. These are the so-called "female" (mother, hostess) and "male" (defender, leader) roles that exist in the form of feminine and masculine rice respectively.

Here is a definition of the concept of "sexual identity".

Sexual identity is awareness of the individual as a representative of one sex or another. Domestic scholars on gender issue T. Govorun and O. Kikinezhdy offer the following definition: "Sexual identity is a subjective understanding, an experience of sexual role, a peculiar unity of sexual self-awareness and behavior" 6 .

Thus, we see that the formation of a "psychological sex" (according to J. Mani) can not take place without the influence of society. Since we are talking about the influence of society on the formation of a subjective experience of oneself belonging to a certain gender, our scientific search should go into the plane of coverage of the gender issue.

\footnotetext{
${ }^{4}$ Говорун Т.В., Кікінежді О.М. Стать та сексуальність: психологічний ракурс. Тернопіль: Навчальна книга - Богдан, 1999. $343 \mathrm{c}$.

${ }^{5}$ Шевченко 3.В. Словник гендерних термінів. Черкаси: видавець Чабаненко Ю., 2016. URL: http://a-z-gender.net/ua/\%D2\%91ender.html (дата звернення 03.05.2019).

${ }^{6}$ Говорун Т.В., Кікінежді О.М. Стать та сексуальність: психологічний ракурс. Тернопіль: Навчальна книга - Богдан, 1999. $343 \mathrm{c}$.
} 
The term "gender" denotes social expectations about the roles that representatives of one or another biological sex must follow. The idea of dividing the gender of a biological and social belongs to the anthropologist Margaret Mead, who voiced this in his work "Gender and Temperament in Three Primitive Societies"7.

During the study of primitive tribes living on the territory of New Guinea, M. Mead came to the conclusion that the independence of such characteristics as "masculinity" or "femininity" from the sex of a person.

The obtained results have allowed a new look at the influence of social and cultural expectations on the formation and consolidation of those or other behavioral patterns of a person.

It should be noted that the term "gender" became much wider after its distribution. In the 1970s, the 20th century, thanks to the works of American scholar Robert Stoller, who proposed the term "gender identity".

According to R. Stoller's views, the biological basis - sex - must be studied within the limits of biology and physiology. And gender, as a social phenomenon, according to $R$. Stoller, must be studied by psychologists and sociologists who study cultural and historical phenomena ${ }^{8}$.

Gender identity is "the experience of its own compliance with gender roles, that is, the set of social norms and stereotypes of behavior characteristic of the representatives of a certain sex"9. It is necessary to distinguish gender identity and gender. Yes, a person can have a clearly defined gender identity and have difficulty with gender: to experience a mismatch with the male and female ideals.

In the structure of gender identity, three components are distinguished:

- cognitive - awareness of belonging to a particular sex and a description of yourself based on the categories of masculinity-femininity. This is the self-concept of a man or a woman;

- assessment - involves the assessment of personality traits and features of role behavior by correlating them with reference models of masculinity-femininity;

\footnotetext{
7 Mead Margaret. Sex and Temperament in Three Primitive Societies (1st Perennial ed.). New York: Perennial an impr. of HarperCollins Publ., 2003. 352 p.

${ }^{8}$ Шевченко 3.В. Словник гендерних термінів. Черкаси: видавець Чабаненко Ю., 2016. URL: http://a-z-gender.net/ua/\%D2\%91ender.html (дата звернення 03.05.2019).

Шевченко 3.В. Словник гендерних термінів. Черкаси: видавець Чабаненко Ю., 2016. URL: http://a-z-gender.net/ua/\%D2\%91ender.html (дата звернення 03.05.2019).
} 
- behavioral - self-presentation of oneself as a representative of a gender group, as well as overcoming the identity crisis by choosing behavior in accordance with the personality of meaningful goals and values ${ }^{10}$.

It is clear that the outlined components of gender identity do not function in isolation but are interconnected. In addition, the defined structure allows for correction (if necessary) to stabilize the image of a person about himself and his social roles (including gender). Since the perception of the person of these components will allow her to understand more deeply about where exactly there is the greatest "strain" in her gender identity. And so she will be able to focus on this.

Gender discrimination is based on gender stereotypes that have emerged in society. Typically, according to these stereotypes, women and girls are considered less significant and have lower social status than boys and men $^{11}$.

However, men also suffer from discriminatory manifestations. They are subject to the "restrictive" stereotypes that encourage boys to be more "masculine", which in turn can increase the appearance of discrimination against women.

Restrictive thoughts about the qualities of the representatives of different sexes do not allow boys and girls to be free to choose their way of life. Because the environment imposes "prohibitions" on manifestations of one or another behavior in accordance with stereotypes "female", "male".

Gender discrimination manifests itself in the fact that the person is not based on his knowledge, skills and professional achievements, but only on the basis of belonging to a certain sex.

A person may encounter various types of discriminatory actions. These actions can take place at school, at work, in communicating with other people. Typically, discriminatory actions include:

- sexual harassment, catcalling on the street;

- gender stereotypes at school and at work;

- objectification (the physical attractiveness is brought to the fore and the person is actually dejected);

- $\quad$ poor representation of women / men in certain activities ${ }^{12}$.

\footnotetext{
${ }_{10}^{10}$ Малкина-Пых И.Г. Справочник практического психолога. М.: Изд-во Эксмо, 2007. 784 с.

11 Challenging gender discrimination: a how-to guide. URL: https://plan-international.org/girlsget-equal/calling-out-discrimination

Challenging gender discrimination: a how-to guide. URL: https://plan-international.org/girlsget-equal/calling-out-discrimination
} 
It should be noted that gender discrimination has deep roots, which is fueled by culture, traditions, religion, etc. That is why it is very difficult to change the gender stereotypes as they are related to the deep layers of the human psyche.

These layers are usually not understood by a person and are absorbed by it from the surrounding environment as a certain "reality" that exists and which does not need to be rethought.

Person simply "swallows up" certain ideas. And these perceptions people perceive as their own beliefs. And therefore he/she is actively trying to defend them and not refuse them.

Such representations, beliefs, settings, etc., which were "borrowed" by a person from the environment, were called "introject". The formation of introject is provided by a process called "introjection".

Introection (from lat intro - inside and lat. jacio - throw, lay) - this is an unconscious psychological process, which belongs to the mechanisms of psychological protection of the psyche. It manifests itself in the "appropriation" of a person's views, thoughts, beliefs of the people around person, which did not belong to himlher before meeting them.

However, as a result of introjection, these thoughts, beliefs, settings, etc., are perceived by the person as their own and transmitted to her inner world. It should be noted that this process of "appropriation" of other people's thoughts takes place at an unconscious level and does not fall under a critical rethink. This term was proposed by Hungarian psychoanalyst Ferenczi Sándor in 1909. Introection is a primitive form of identification, but unlike the identification, introjection is not realized ${ }^{13}$.

The concept of introjection further develops in gestalt therapy, the founder of which was F. Perls. In the Gestalt approach, the appearance of introject is also due to the transition of external rules to internal rules. They explained this process based on the analogy with the process of absorption of food, when a person "swallows" everything that the surrounding world gives her/him without a critical reflection of what person "consumes",

The presence of introjects in the human psyche is a factor that ensures the formation of a huge number of attitudes and sets, which begin with the words "I must".

\footnotetext{
${ }^{13}$ Мак-Вильямс Н. Психоаналитическая диагностика: Понимание структуры личности в клиническом процессе. М.: Класс, 1998. 480 с.

${ }^{14}$ Перлз Ф. Практика гештальттерапии. М.: Институт Общегуманитарных Исследований, 2005. 480 с.
} 
There are no exceptions to the introjects that regulate the functioning of the person at the level of gender roles. That is why, on our way of life, we can meet a large number of adults who operate categories that are introjects in nature. For example, "a man must be strong", "a woman must be weak", and so on.

Sandra Bem made a significant contribution to understanding the concept of gender and stereotypes related to this concept. In her work "Gender Lens: The Transformation of Views on the Problem of Sexual Inequality" (1993), the researcher proposes a model for gender stereotypes and develops the theory of gender schemes ${ }^{15}$. According to this theory, sexual typing occurs on the basis of gender schematization, which manifests itself in the ability of children to codify and organize information, including self / self, in accordance with the cultural definitions of male and female. Thus, this theory emphasizes that sexual typing occurs on the basis of cognitive processes that are present in the child.

However, in the theory of gender schemes it is emphasized that sexual typing is not only the cognitive activity of the child himself/herself. But this is also the process of social learning, in which the child is faced with the fact that her/his certain behavioral manifestations are supported by adults, while others are not. Thus, there is a process of learning that incorporates socially established stereotypes about "female" and "male" roles.

Gender research sooner or later brings researchers to the issue of gender discrimination. Particularly relevant is the question: how to counter gender-based discrimination. And what is the role of youth in supporting or opposing discriminatory processes in society. That is why our empirical study aimed to identify the peculiarities of gender-based discrimination on the part of young people.

As we see, the issue of gender discrimination has deep roots and needs to be studied not only at the social level, but also at the deep-personal. Our study concerned only the social level and determined the "actual" limits of social existence of this phenomenon. However, we understand that the prospect of research on the gender issue is the study of the underlying processes that unfold during the formation of the individual and which, in turn, will influence the further deployment of her/his life path.

\footnotetext{
${ }^{15}$ Бем С. Линзы гендера: Трансформация взглядов на проблему неравенства полов / [пер. с англ.]. М.: «Российская политическая энциклопедия» (РОССПЭН), 2004. 336 с.
} 
The formation of a life path under the influence of unconscious decisions taken in childhood brings us to the concept of a life-script that was developed within the theory of transactional analysis. Researchers of the theory of transactional analysis studied the formation of "female" and "male" life-scripts under the influence of unconscious decisions of the individual ${ }^{16}$. This problem has a significant scientific potential and needs more detailed study in our further research. In this paper, we are doing a brief overview on of how young people (students) see gender discrimination.

\section{Gender discrimination: student's view of this phenomenon}

Our research was conducted at the V.I. Vernadskyy Taurian National University (Kyiv). Participants in the survey: permanent residents studying in the fields of psychology, social work, history and archeology and secondary education. Total number of respondents: 51 students (14 boys and 37 girls). The average age of the subjects 19 years. It should be noted that all participants in the survey did not receive training, lectures or special courses on issues of discrimination, including gender-based discrimination. The survey was conducted in the form of a written questionnaire and took place in April 2019.

Procedure of the study: respondents were given questionnaires with a list of questions they were supposed to give a written answer. If a student has some difficulties, he/she raised his hand and the experimenter gave him/her some help: answered the clarifying questions. Students did not have time limits for completing the questionnaire. The average time for filling in the questionnaire was 20 minutes.

Also, after completing the questionnaire with students, a mini-lecture was held with a follow-up discussion on what gender-based discrimination it is. Such discussion allowed to determine the features of understanding the phenomenon of discrimination by student youth. Also, this form of polling organization has made it possible to compare their representations (written answers) with what is described as gender discrimination in accordance with international and national documents.

\footnotetext{
${ }^{16}$ Steiner C. Scripts People Live: Transactional Analysis of Life Scripts. Grow Press: New York, 1990. 332 p.
} 
The obtained data was entered into the SPSS program, which provided quantitative data analysis. However, for a deep understanding of how the concept of "gender discrimination" is interpreted by young people, we carried out a qualitative analysis of the data.

The questionnaire contained open questions that required an expanded answer from the students' side. In particular, young people were asked to define what "gender discrimination" means; Determine whether discrimination is a biological or social basis. Describe the cases when they encountered gender discrimination in their own lives. There was also a question as to whether they displayed gender-based discrimination in relation to others.

This list of questions allowed to determine the number of discriminatory cases that occurred in the life of a young person. The open form of the question allowed to determine the specificity of this discrimination. The final question was whether students want more information on gender discrimination and in what form (lectures, trainings, discussions, etc.).

It is clear that such a number of subjects does not allow us to extrapolate the results obtained to all student youth of Ukraine. However, the purpose of this survey was to determine if there is a general demand from young people for a "meeting" with such a topic, and their desire to receive additional knowledge on inequities.

The question about the grounds on which gender discrimination is based (biological or social), the majority of respondents (41 students, $80 \%$ ), attributed to a socially determined phenomenon. The biological basis was determined by 4 respondents $(8 \%)$, a combination of biological and social 6 subjects (12\%). The illustrated results are presented in Fig. 1.

As we see, the vast majority of students regard gender discrimination as having a social basis. Thus, for most young people, discriminatory manifestations do not find their explanation in the area of biological differences between women and men.

Answers to the question "Have you encountered in your life with gender discrimination?" Answered the young people in the following way: 28 respondents answered positively (55\%), negatively 23 students (45\%). The distribution is presented in Fig. 2. 


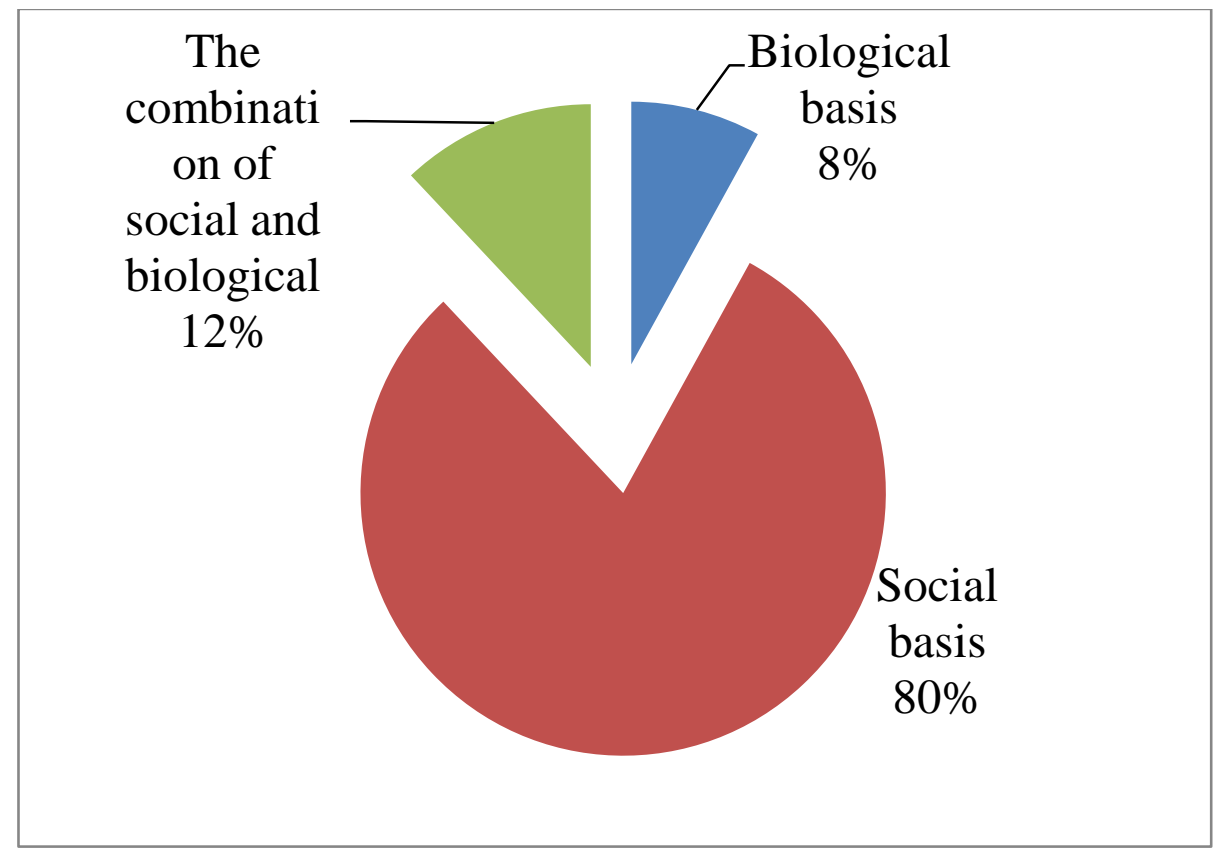

Fig. 1. Distribution of respondents on the question of the basis of gender discrimination

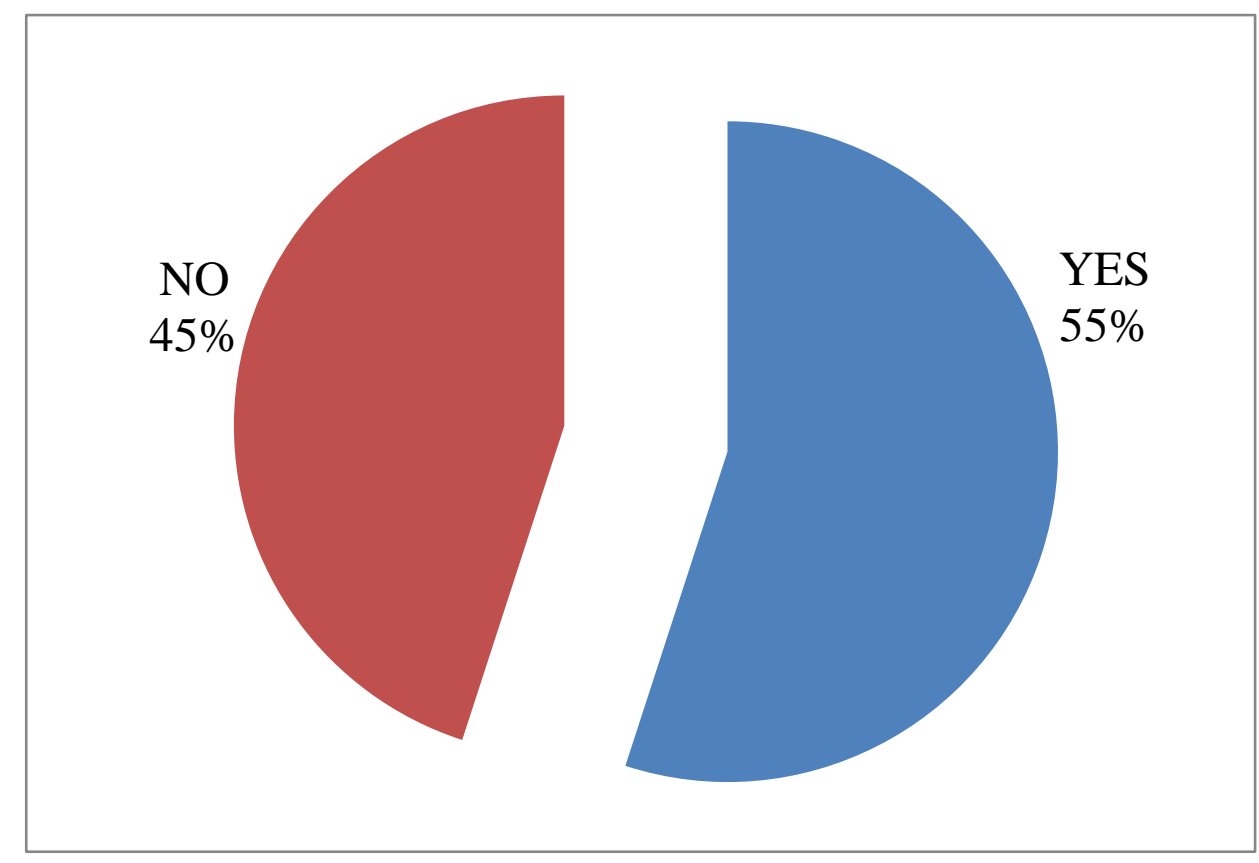

Fig. 2. Distribution of respondents to the question "Have you encountered gender-based discrimination in your life?"

The results suggest that young people meet in their lives with gender discrimination. However, we also see that $45 \%$ of respondents indicated that 
they did not face discrimination. It should be noted that after the questionnaire we also had a mini-lecture with a further discussion on what gender-based discrimination is.

Thus, among respondents who gave a negative answer to the question "Have you encountered gender discrimination in your life?". Some of them did not have sufficient level of awareness on this issue and did not include stereotyped statements, anecdotes, etc. to gender discrimination. In particular, the statement that "a woman, above all, mother, and then everything else" does not regard them as a manifestation of discrimination. In relation to a man, the stamp "men - do not cry" indicated that all respondents $(100 \%)$ heard, but did not attribute it to a discriminatory component. In this way, we see that in Ukrainian youth there is a certain "resistance" to such kind of stable discriminatory statements. The results suggest that the issue of educating young people on gender issues is of great importance for modern Ukrainian society.

It should be emphasized that for our study, a qualitative analysis of the data was important. The quantitative indicator was important in the context of whether a person was exposed to discrimination in his/her life. Because the number of respondents for us was an indicator of whether this issue is relevant to Ukrainian society as a whole, and for student youth in particular.

However, the purpose of this survey was to determine the specificity of understanding and attitude of students towards the manifestations of gender discrimination. That is why, in most cases, the qualitative indicators of the conducted research (examples of answers) are given, rather than quantitative ones. It should be noted that some definitions were duplicated by some students, but they still had their own specifics, which distinguished this answer from the responses of other participants in the study.

One of the questions that contained the questionnaire was the definition of gender discrimination and its understanding by young people. A large number of respondents attribute gender-based discrimination to violation of rights, especially women, when they can not fully realize themselves in society, in particular, under the pressure of the "male world".

Here are some of the definitions of gender discrimination that students have given: "This is the benefits of men (in most), oppression of women's rights"; "When someone is humiliated in rights"; "It impedes the rights of people of a certain sex, for example, it is believed that women are a weak sex"; "The oppression of one sex or another in all spheres of life"; 
"...."female" and "male" roles that do not take into account the person's predisposition and limit their rights and freedom"; "When women and men are not equal in their rights", "When a man humiliates his wife and does not allow her to be realized in the profession, because work is "for intelligent and strong men".

Students also associate this term with the process of humiliation: "Gender discrimination is the humiliation of someone on a gender basis"; "Humiliation by sex, gender"; "Gender discrimination is a situation where women and men are not equal in rights and abilities and beliefs about them"; "When women and men are not equal", "Humiliation on the basis of sexual identity".

Gender discrimination was also linked to the existence of certain privileges, advantages on the one hand (and their absence from the other): "the existence of certain privileges for one sex (women, men)"; "... preference is given to a person of one sex in different spheres of life: during employment, remuneration of labor, manifestation of sexual harassment, domestic violence".

Students also linked discrimination with the ability to choose a professional path by the personality and the presence of an established division of responsibilities in society: "This impediment of the right to choose a profession and professional implementation", "This is a clear division of responsibilities".

Some students did not differentiate between sex and gender, defining gender discrimination as "Judging a person based on her/his sex". It should be noted that such an interpretation does not go beyond the generally accepted definition. Since the general definition of gender discrimination is presented as "sex-based discrimination"17. Thus, the lack of definition of the word "gender" does not go beyond what has been accepted.

It should be noted that in most cases, we have seen definitions that were intended to emphasize the impact of the actual non-biological sex, and the social expectations and stereotypes associated with the sex. That is, this led to the concept of gender as a social category.

Here are some examples of student definitions that include a social component in the context of gender discrimination: "Discrimination based on sex associated with stereotypes of society."

\footnotetext{
${ }^{17}$ Виртосу I. Гендерна дискримінація: Як не наступити на граблі старими мозолями? URL: https://humanrights.org.ua/material/gendernajia_diskriminacijia_kak_ne_nastupit_na_grabli_starymi_mozoljiam і (дата звернення 04.05.2019).
} 
As we see, in most cases, students associated discrimination with the phenomenon of inequality, oppression of rights and the pressure of certain stereotypes that prevent a person from fully revealing his/her potential and choose the life path that he/she likes.

Interpreting the results of the number of students who encountered gender discrimination would not be complete without a qualitative analysis of the responses of young people. The qualitative component was obtained through the question "Give an example when and how you encountered gender discrimination".

A significant number of respondents indicated that they were faced with discrimination on the basis of sex in the labor market (in the process of employment). Thus, a vivid manifestation of gender discrimination was an example when a student described that she was not working with an employer who was "male". The student noted that the work was to compile tables for the company. Thus, we see discrimination at the level of mental impairment due to being a female. In addition, a significant number of respondents indicated that they encountered such restrictive phrases as "This is not a women's affair".

An interesting example was the response that demonstrated the presence in Ukraine of so-called reverse discrimination, which manifests itself in discriminating against the majority (representatives of the dominant group) by members of the minority group. For example, a man may be denied a job because of the fear of accusations of sexism if a woman is a competitor to this position" ${ }^{18}$ "I met the fact that in some companies the advantage is on the contrary given to women, especially if they are representatives of the LGBT community", said one of the students in the poll.

Examples of discriminatory experiences were as follows: "I often hear from others: "What do you want from her, she's the girl" or "You still do not understand me, you're the girl". In these examples, we see a biased attitude towards another gender based on prevailing social stereotypes.

Students who demonstrated their desire to identify their personality beyond the established stereotypes (in particular, on the level of image) demonstrated their particular pressure. Such students encountered resistance and received phrases such as "You are a girl, you have to wear a dress!”.

18 Шевченко 3. В. Словник гендерних термінів. Черкаси: видавець Чабаненко Ю., 2016. URL: http://a-z-gender.net/ua/\%D2\%91ender.html (дата звернення 03.05.2019). 
If we talk about stereotypes (and they are themselves related to gender discrimination), then it should be noted that they have many imperatives, that is, a high level of compulsory nature. This obligation is manifested in phrases such as "you must" with further condemnation from the environment if a person shows intention not to go through the established "duty" and defines for himself/herself other priorities.

Today, the term "stereotype refers to the established pattern of thinking, prejudice, which, as a rule, has no direct relation to reality. The term was proposed by U. Lippmann (1922), which became part of the socio-political discourse of Western European countries, and then spread to other countries. Today, the study of stereotypes is carried out within the limits of psychology, social psychology, especially in the context of the problems of discrimination.

The main question is: "Why do people use stereotypes?". The answer is simple. With the help of stereotypes, a person saves the resources of his psyche, because the presence of stereotypes simplifies the vision of the surrounding reality. For example, stereotypes about men and women can allow a person to make certain "conclusions" about the person with whom he/she communicates. Thus, a person has a certain intention to react to an interlocutor before he or she answers. And what can be expected from the person with whom you enter into interaction (the "prognostic" function of stereotypes).

The stereotype is not reality, it's a strategy for simplifying reality. Since, having certain stereotypes, people are more likely to process incoming information and give an answer. It is clear that such a response is very simplistic and incapable of taking into account the individuality of the subject with which this person communicates.

In the context of gender stereotypes, we have such patterns as "women - emotional beings", "men - rational beings". Therefore, often we question the woman's ability to make rational, weighed decisions. And we see men as being deprived of emotion. It is clear that such stereotypes do not correspond to reality.

However, during the historical formation of mankind, they deeply entered the society. And since stereotypes are formed rather early (in childhood), it is difficult to rethink them in adult life. However, due to special education and psychological training, significant changes can be made in the context of changing stereotyped attitudes, in particular gender issues and gender discrimination. 
Respondents also noted that in relation to them were put forward requirements for the implementation of her future reproductive function: "Do not raise the hard, you have children to give birth". In this example, we see the stereotypical representation of society, which often places the mother in the forefront of women. Other roles (business lady, traveler, etc.) are considered as minor, or in general, as non-eligible. We remember a wellknown saying about what should go to a circle of women's interests: children, cuisine, church. It is clear that such stereotypes restrict the woman in her quest for the realization of her potential as a person.

Also, the respondents cited examples of discriminatory jokes that are often heard in the direction of a woman: "Your place in the kitchen", "Silence, woman, your day is the eighth of March". Examples of women's ability to drive a car (negative assessment): "All problems on the roads, through female drivers".

In addition, men were discriminated against in their ability to raise children (devaluing their abilities in comparison with women). They gave examples of communication with older generations when they believe that "a man to go to maternity leave is ashamed".

Students also said that they faced discrimination when women were told that they had to "cook, clean the house", that is, to fulfill "female" duties.

Young people often encounter life situations (on an example of a parent's family or friends and relatives' families) when a man drops all his domestic work to a woman by motivating it, "You are a woman, you have to lead a housekeeping".

Respondents also noted that since childhood they had heard that girls should be feminine, beautiful; and the task of a man is to be rich. The girl must find her prince and marry him. The fact that women should not grow professionally and earn less than their husbands. Thus, we see that from a childhood a stereotype is built where a woman is a passive addictive being whose main purpose is to marry a man. And its professional growth and financial independence are not considered as a priority at all.

In addition, students (women) met with stereotyped beliefs that women do not have a place in politics, business.

Respondents also pointed out, as an example of gender discrimination, the situation with the rights of women in Islamic countries (for example, a ban on driving in some countries of the East). 
Some respondents cited historical examples of gender discrimination, in particular, the example of Antiquity, when the woman in fact did not have any rights.

Answering the question "Have you shown discrimination against others?" Respondents distributed as follows: 15 respondents (29\%), 36 students (71\%) negatively responded (Fig. 3).

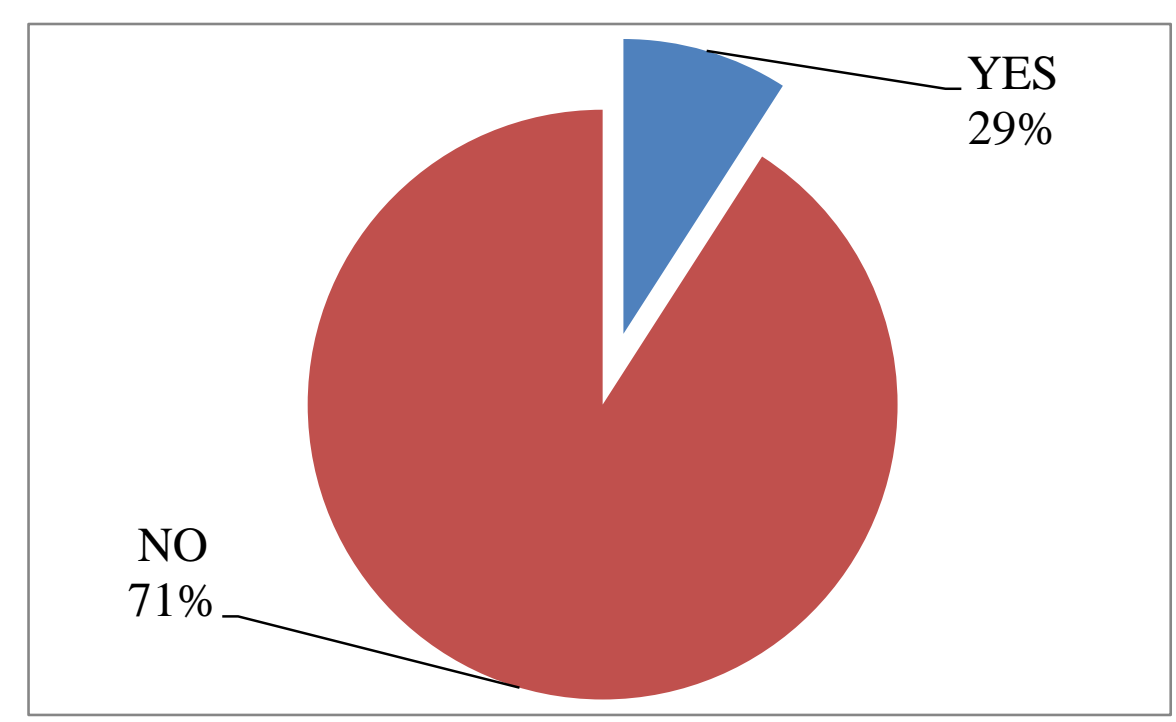

Fig. 3. Distribution of respondents by question, whether they showed gender discrimination to others

The following examples illustrate the discrimination of young people. So, the student noted that at work she sent to pick up a certain product of men, and to engage in documents appointed women.

On the part of male representatives, an example was presented (which had a negative connotation) about meeting with representatives of the feminist movement: "they met "totalitarian human rights activists" more often".

Some respondents indicated that they did not manifest external manifestations of discrimination, but "inside themselves" felt, for example, contempt for a man who behaved too "feminine". This remark brings us to an understanding that the absence of a demonstration, the manifestation of discriminatory actions, does not mean the absence of discriminatory stereotypes.

The most important thing in this situation is the subsequent actions of the subject: what he/she will do with his convictions. A possible way, 
when a person, based on the reflection of himself/herself, his/her life experience, information obtained from open sources can reach the conclusion about the "perniciousness" of imposed stereotypes. It will try to rethink them and change them. Here the vital activity of the subject must take place.

In another deployment of events: the reflection is low, a person does not want to meet the experience of another person and returns to a simpler level of functioning - to stereotypical representations. And for such a deployment of events, this in the future may lead to open discriminatory manifestations.

In addition to gender discrimination, students identified their expectations as to what should be done by representatives of another gender, that is, what they were supposed to show by sexually modeled behavior. And if this behavior did not fit into the commonly accepted option, young people felt "somewhat confused" and "annoying".

In terms of gender discrimination, young people identified the following examples. In particular, they (as representatives of the "strong sex") should give way to women in public transport. Of the 14 boys, 5 respondents turned their attention to it $(36 \%)$.

Students, meanwhile, described as an example of discrimination that only men are liable for military service to Ukraine (for women, service in the army is not compulsory). Two respondents from 14 boys (21\%) focused on this.

One student noted that he sometimes discriminates in the form of irony in relation to himself: "I am a man, I have to work at a factory". In this example, we see that with humor, a young man tries to overcome stereotypes and go beyond its limits.

Also, discrimination against men was noted by boys for the need to pay their bills for "their girlfriend" (in cinema, cafes, travels). 4 respondents drew attention to this (29\%). This result emphasizes once again the importance of women's financial independence from her husband.

One of the boy mentioned the following example of discrimination: "I had long hair for several years, I received mockery and harassment from both young people and adults".

Answers to the question "Would you like to receive more information about gender discrimination?". The respondents answered the following distribution: 43 (88\%) wrote that they were interested in this topic and they 
would like to receive additional information, 6 students (12\%) said that they do not want to receive additional information. Such a division allows us to talk about the high level of relevance of the issue of gender-based discrimination. We see that young people seek to broaden their knowledge of understanding discrimination, its manifestations and possible prevention in Ukrainian society.

Consequently, the chosen topic of research is relevant and requires a detailed study. The obtained results give grounds for talking about the need to highlight the topic of gender discrimination, especially in the psychological context.

We believe that the study of discrimination should be based on the work done by scholars from around the world. It should be emphasized that genderbased discrimination should be investigated by representatives of various scientific fields in order to enable them to understand the origins of this phenomenon. In particular, this problem should be studied by psychologists, sociologists, anthropologists, historians.

An understanding of the origins of discrimination in the context of women's financial and economic dependence on men is also important. Therefore, the study of this issue would be incomplete without representatives of economic science. The formation of independent, successful women who have the right to influence socially meaningful decisions is impossible without involving women in the political sphere, and therefore one can speak about the role of political science in solving gender discrimination.

As we see, the issue of gender-based discrimination is broad and multilevel. It requires considerable efforts from scholars and public representatives to study it and outline ways to overcome gender-based discrimination.

\section{CONCLUSIONS}

As a result of the theoretical and empirical research, we have clarified the concept of "gender", "gender identification", "gender discrimination"; the history of the emergence and formation of these phenomena is presented. The theoretical analysis made it possible to identify the countries that were the first to identify the priority of combating the manifestations of gender discrimination.

In the context of contemporary Ukrainian society, the study of genderbased discrimination needs more attention. Particular importance is given 
to the desire of young people to step outside the discriminatory space and their desire to go their own way, not through stereotypes. The primary focus in this context is educational activity that helps young people to understand the perniciousness of stereotypes and gives the feeling that everyone has the right to be and can determine the priorities of their personal growth for themselves.

The obtained results made it possible to determine the peculiarities of understanding the gender discrimination of the student youth of Ukraine. It is clear that the study procedure allowed to identify only general trends in the issue of gender-based discrimination. Our scholarly search in the future will include a deeper psychological analysis of the attitude of young people towards gender inequalities and discrimination.

\section{SUMMARY}

This article is devoted to the study of gender-based discrimination in the context of the view of this phenomenon by student youth. Gender discrimination is a phenomenon that arose a century ago and which, unfortunately, continues to exist. In the modern world, the most attention to this problem is paid to such countries as: USA, Canada, Sweden and other countries of Western Europe. In Ukraine, research in this area takes place, but needs a more practical component: the theory should be implemented in practice.

That is why this article raises the question of asking young people for information on gender discrimination. In addition, the coverage of gender discrimination raises questions about a new perspective on the role of women and men in building family relationships. It is very important for young people.

The research revealed the specificity of gender discrimination on the part of student youth. It has shown that students associate this type of discrimination with human rights violations, with the pressure of society on a person, which limits her/his freedom to be what the person wants.

The survey showed a significant percentage of young people who have been exposed to gender discrimination in their lives: in daily and professional communication.

The obtained results actualize the question that modern youth tends to change the social stereotypes that restrict the choice of personality. These issues are particularly acute in the context of gender-based discrimination. 
Because, whatever the person whoever she was, would be forced to face social expectations about his/her gender.

Such expectations often have too much impact on human behavior and its ability to make informed and independent choices about oneself and in their livelihoods. And if the young person does not know and does not know that any phenomenon faced by a person has to undergo a certain level of critical reflection in order to understand the difference between what "I feel" (personal level) and those "so it should be" (social expectations and stereotypes), it's almost impossible to get out of stereotypes.

The ability to implement active psychological work (reflection) at the level of the individual will allow a person to identify "white spots" of his/her ignorance and expand the scope of his understanding. Such "extended" awareness allows you to go beyond the established stereotyped framework and look at yourself and the world in a different way. And, therefore, it provides an opportunity to take steps to overcome discrimination, including gender-based discrimination.

\section{REFERENCES}

1. Бем С. Линзы гендера: Трансформация взглядов на проблему неравенства полов / [пер. с англ.]. М.: «Российская политическая энциклопедия» (РОССПЭН), 2004. 336 с.

2. Виртосу I. Гендерна дискримінація: Як не наступити на граблі старими мозолями? URL: https://humanrights.org.ua/material/gendernajia_ diskriminacijia_kak_ne_nastupit_na_grabli_starymi_mozoljiami (дата звернення 04.05.2019).

3. Говорун Т.В., Кікінежді О.М. Гендерний дискурс в психологічній науці та педагогічній практиці. Психологічний часопис : збірник наукових праць / за ред. С.Д. Максименко. Київ: Інститут психології імені Г. С. Костюка Національної академії педагогічних наук України. № 1 (3). 2016, 200 с.

4. Говорун Т.В., Кікінежді О.М. Стать та сексуальність: психологічний ракурс. Тернопіль: Навчальна книга - Богдан, 1999. $343 \mathrm{c}$.

5. Кембриджський словник URL: https://dictionary.cambridge.org/ (дата звернення 01.05.2019). 
6. Мак-Вильямс Н. Психоаналитическая диагностика: Понимание структуры личности в клиническом процессе. М.: Класс, 1998. $480 \mathrm{c}$.

7. Малкина-Пых И.Г. Справочник практического психолога. М.: Изд-во Эксмо, 2007. 784 с.

8. Ожегов С.И., Шведова Н.Ю. Толковый словарь русского языка (А-Д) Издательство “Азъ”, 1992.

9. Перлз Ф. Практика гештальттерапии. М.: Институт Общегуманитарных Исследований, 2005. 480 с.

10. Словник украӥнської мови : [в 11-ти т.] / [ред. кол.: І.К. Білодід (гол.) та ін.]. Київ: Наукова думка, 1970-1980. Т.2: Г-Ж / ред. тому: П.П. Доценко, Л.А. Юрчук. 1971. 550 с.

11. Шевченко 3.В. Словник гендерних термінів. Черкаси: видавець Чабаненко Ю., 2016. URL: http://a-z-gender.net/ua/\% D2\%91ender.html (дата звернення 03.05.2019).

12. Challenging gender discrimination: a how-to guide. URL: https://plan-international.org/girls-get-equal/calling-out-discrimination (дата звернення 30.04.2019).

13. Mead Margaret. Sex and Temperament in Three Primitive Societies $\left(1^{\text {st }}\right.$ Perennial ed. $)$. New York: Perennial an impr. of HarperCollins Publ., 2003. 352 p.

14. Steiner C. Scripts People Live: Transactional Analysis of Life Scripts. Grow Press: New York, 1990. 332 p.

Information about author: Kostina T. 0.

Candidate of Psychological Sciences, Associate Professor at the Department of Psychology and Pedagogy of the V. I. Vernadsky Taurida National University 33, Ivana Kydri str., Kyiv, 01042, Ukraine 